\title{
Nosocomial Infections Distribution and Impact in Medical Units
}

\begin{abstract}
LIVIA CLAUDIA STANGA ${ }^{1}$, DELIA MIRA BERCEANU VADUVA1,2*, MIRELA LOREDANA GRIGORAS ${ }^{1 *}$, LAURA ALEXANDRA NUSSBAUM ${ }^{1}$, DANIELA GURGUS ${ }^{1 *}$, LILIANA STRAT ${ }^{3}$, ALEXANDRA SIMONA ZAMFIR ${ }^{3}$, VLADIMIR POROCH ${ }^{3 *}$, ROXANA FOLESCU1

IVictor Babes University of Medicine and Pharmacy, Department of Microbiology, 2 Eftimie Murgu Sq., 300041, Timisoara, Romania

${ }^{2}$ Dr. Berceanu Clinical Laboratory, 7 Teiului Str, 300659, Timisoara, Romania

${ }^{3}$ Grigore T. Popa University of Medicine and Pharmacy, Faculty of Medicine, 16 Universitatii Str., 700115 lasi, Romania

Currently, morbidity through nosocomial infections is significantly increased in all countries of the world, which is why it has become a priority public health issue that can be a criterion for assessing the quality of health care and service management. The purpose of our study was to assess the impact of nosocomial infections type, distribution and frequency in cardiovascular units. Between 2014 and 2018, 87 samples were collected for sterility testing in two cardiovascular departments in Timisoara. Hydrophobic cotton swabs, twisted and bonded to the head of a wooden rod that were placed in a sterile tube or sterile collectors without media, plastic, were used as harvesting material. Most were samples for controlling instrument and soft sterility with a temporal distribution. The results revealed that some samples showed coagulasenegative Staphylococcus aureus (SCN) strains. For a good knowledge of the possibilities of prevention and control of nosocomial infections, it is necessary first of all to know the reality of this type of pathology, respectively to make the surveillance strategies more efficient, in all sanitary units, according to the existing legislation and professional protocols for prevention and control.
\end{abstract}

Keywords: nosocomial infections, antibiotics, epidemiological surveillance strategies

Since the 1970s, there has been an increase in the prevalence of nosocomial infections due to: excessive use of broad spectrum antibiotics and cephalosporins under which multi-resistant microbial strains were sellected (methicillin-resistant Staphyloccoccus aureus - MRSA, extended-spectrum beta-lactamase - ESBL, VancomycinResistant Enterococci - VRE), increasing the invasiveness of diagnostic and therapeutic procedures, caring for a greater number of individuals with high risk immunosuppressed persons or with pre-existing chronic morbidity, increasing the incidence of viral etiology or micotics pathology, the occurrence of emerging infections as well as the neglect of the control system by nonobservance by medical personnel of universal precautions and non-adaptation to the nosocomial infection surveillance system [1-3].

Nosocomial infections remain a tangible contemporary reality in all hospital settings. There is a strict correlation of these infections with the architectural structure, hospital care potential, its capacity to prevent infections and, last but not least, with the level of education or training of healthcare professionals [4-6].

The antibiotic resistance of circulating bacterial strains in a hospital directly reflects the competence of doctors in antibiotic therapy $[7,8]$.

Patients admitted to surgery, intensive care, hematology, oncology, immunosuppression, prematurity, dystrophies, catheterized patients, polydips or long-term hospitalizations are the most exposed to nosocomial risk. So, it is precisely the patients who benefit today more from the quality of care who are the most vulnerable, which paradoxically causes a decrease in their chance of survival by exposure to infectious complications. In this situation, only discipline and strict supervision of hygiene rules in hospitals can control nosocomial infections and, ultimately, the chance of survival of these patients [9-12].
Currently, morbidity through nosocomial infections is significantly increased in all countries of the world, which is why it has become a priority public health issue that can be a criterion for assessing the quality of health care and service management [13-15].

Interpretation of surveillance results is based on quantitative and qualitative indicators on: the incidence of nosocomial infections by reporting the number of new cases occurring in a time unit to the total number of hospital discharge from the same time interval; the prevalence of nosocomial infection by reporting the total number of existing nosocomial infections in a unit of time established in the number of patients existing in the hospital / department [16-18].

\section{Experimental part}

Between October 2014 and October 2018, 87 samples were collected for sterility testing in the two cardiovascular departments in Timisoara.

Hydrophobic cotton swabs, twisted and bound to the head of a wood rod that is inserted into a sterile tube or non-plastic sterile collector, are used as harvesting material. Prior to use, the dry pad is moistened with $1 \mathrm{~mL} 1 \%$ peptone water or $1 \%$ peptone physiological saline added to the tube or collector.

The materials used to collect samples are:

-hand samples; wiping the palm of the right hand and fingers with the prepared swab, insisting in the peri-angular and interdigital areas, and passing the swab 2-3 times over each area, rotating itcontinuously. There are up to $40 \mathrm{germs}$ on hand allowed for the hands of the staff in contact with the patient. The presence of enteropathogenic E. Coli, Proteus, pathogenic Staphylococcus or other pathogenic germs is not allowed.

\footnotetext{
*email: deliaberceanu@yahoo.com, mirela.grigoras@yahoo.com,daniela.gurgus@gmail.com,vladimir.poroch@umfiasi.ro
} 
-check of the machine in the food blocks; the check is carried out on dishes and kitchenware, in imminence of being used (therefore considered clean). The examination is made in the hospital kitchen, as well as in the hospital offices and wards. The presence of enteropathogenic $E$. Coli, Proteus, pathogenic Staphylococcus or other pathogenic germs is not permitted.

-microbiological check of surfaces and soft inventory, sampling is done on the wall tiles or oily walls, tables, bed sheets, blankets, beggars, etc. Each sample is collected with a hydrophobic cotton swab to erase a $10 \mathrm{~cm} / 10 \mathrm{~cm}$ delimited area. Surface removal is done by passing the swab 2-3 times in different directions, with its simultaneous rotation, over the entire surface $\left(100 \mathrm{~cm}^{2}\right)$. The control of surface disinfection and soft inventory is investigated: the presence of bacillus coli, the presence of protease bacillus, the presence of hemolytic Staphylococci. The examination of surface disinfection and soft inventory is investigated: the presence of $E$. Coli, the presence of Proteus, the presence of hemolytic Staphylococci.

For each swab, after each collection, $9 \mathrm{~mL}$ of $1 \%$ peptone water is added. After a 10-15 min rest, hard shaking is made to homogenize the bacterial concentration, resulting in the crude work suspension.

To determine the number of germs from the crude suspension, a $1 / 10$ dilution in $1 \%$ peptone water is made. From both the crude suspension and the decimal dilution, $1 \mathrm{~mL}$ of $2 \%$ melted agar is added and cooled to $45-50^{\circ} \mathrm{C}$, poured into Petri dishes. After $48 \mathrm{~h}$ of incubation, colonies developed on the two plates of each sample are counted (gross suspension and decimal dilution).

The result refers to $1 \mathrm{~cm}^{2}$ of surface area according to the following formula:

$($ Gross suspension $\times 10)+($ Decimal dilution $\times 100)=$ germs $/ \mathrm{cm}^{2}$ $2 \times$ Surface of the pattern $\left(100 \mathrm{~cm}^{2}\right)$

To determine the pathogenic microbial strains, seed suspension is performed on blood-agar and Mac Conkey, and after $24 \mathrm{~h}$ of incubation at $37^{\circ} \mathrm{C}$, bedding of the suspicious colonies from blood-agar to the Chapman medium and, if necessary, repeating on the Mac Conkey medium.

\section{Results and discussions}

There are up to 40 germs on hand for the hands of the staff in contact with the patient. The presence of enteropathogenic E. Coli bacillus, S. aureus, or other pathogenic germs is not allowed on hand.

In order to check sterility, test tubes are necessary, preferably those of $180 / 18 \mathrm{~mm}$ containing $10-15 \mathrm{~mL}$ glucose broth. Checking the sterility means either the direct introduction of the object to be controlled in the culture medium or wiping the object with a swab which is eventually sown, or by washing the object in the medium or other liquid which is then passed to the culture medium.

Syringe needles, puncture needles, suture needles, dental needles, collars, surgical stitches, small compresses or sterile cut compresses, teats and any other instrument and material that can be sampled as such will be sown on the spot in the environments of culture in the tubes.

The elongated surgical instrument, which exceeds the height of the culture medium container, is introduced with the distal end into the medium container, washed by a slight stirring, after which the instrument is removed and the cotton plug is applied to the tube.

The sterile water from operators of the operating blocks is directly seeded $5-10 \mathrm{~mL}$ in a mouthpiece with $10-50 \mathrm{~mL}$ glucose broth after the tap has been flapped and the water is allowed to flow for 1-2 min.

All samples sown on media were maintained at $37^{\circ} \mathrm{C}$ and their sterility followed for 7 days. In non-sterile samples (broth broth), germs are identified. To determine the pathogenic microbial strains, the suspension is sown daily on blood-agar, Chapman, Mac Conkey media.

Eighty seven samples were collected for sterility testing in 2 departments of cardiovascular surgery, as follows (fig. 1).

Most samples were collected for examining sterility of instruments and soft material, with a temporal distribution highlighted in the table below (table 1).

Two samples from 2014, one of sterile water and one of sterile soft material showed coagulase-negative Staphylococcus aureus (SCN) strains (table 2).

Based on literature data, in socio-economically developed countries and with a functional health-care system, with all professional and material effort, the prevalence of nosocomial infections is between 5 and $21 \%$ of the medically assisted and has a steady growth trend [19-21].

In Romania, although some targeted investigations / assessments indicate a significant frequency of nosocomial infections, the proportion of those recognized, diagnosed and / or reported is, in most medical units, well below $1 \%$ of those medically assisted $[22,23]$.

In a number of countries, such as the U.S. and the European Community (34 studies involving over 2 million patients), the average prevalence of nosocomial infections ranges between 5 and $12 \%$ of assisted persons, with an incidence per 100 patients discharged from $1-7 \%$ in surgery, $5-6 \%$ in pediatric services, $10-15 \%$ urology [2426].

Today, in Romania, we have no compelling data on actual mortality through nosocomial infections than in regrettable accidents. Also, only sporadic information on assessments related to the number of days of hospitalization and persistent etiologies or multi-resistant micro-organisms is available.

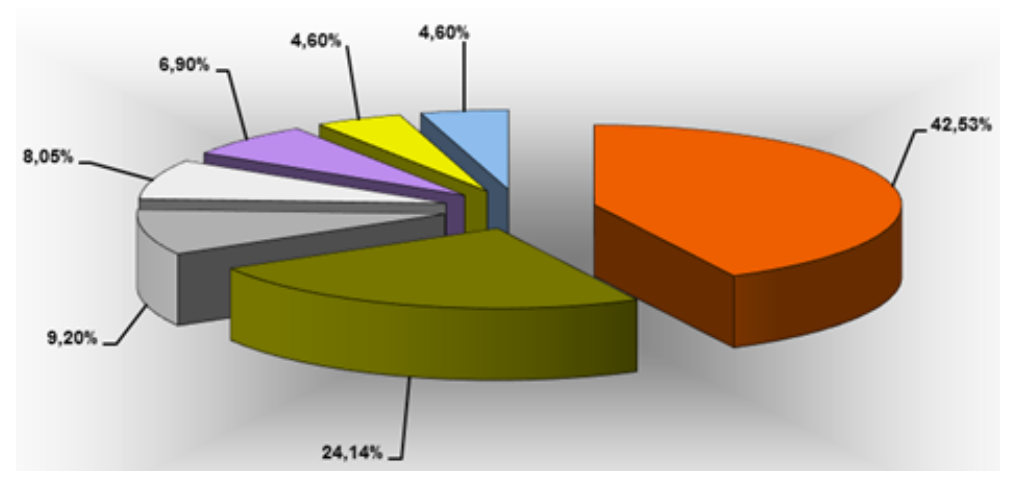

Fig. 1. Distribution of the types of sterile materials tested in surgical departments $(I+I I)$ 


\begin{tabular}{|c|c|c|c|c|c|}
\hline Year & Sample Type & $\mathbf{n}$ & $\%$ & \multicolumn{2}{|c|}{ 95\% C.I. } \\
\hline \multirow[t]{5}{*}{2014} & Sterile water & 1 & 7.69 & 0.20 & 36.00 \\
\hline & Sterile instruments & 5 & 38.46 & 13.90 & 68.40 \\
\hline & Soft sterile material & 5 & 38.46 & 13.90 & 68.40 \\
\hline & Intubation tube & 2 & 15.38 & 1.90 & 45.40 \\
\hline & Totally & 13 & 100.00 & & \\
\hline \multirow[t]{8}{*}{2015} & Water sparge & 1 & 7.14 & 0.20 & 33.90 \\
\hline & Sterile water & 1 & 7.14 & 0.20 & 33.90 \\
\hline & Sterile instruments & 5 & 35.71 & 12.80 & 64.90 \\
\hline & Soft sterile material & 2 & 14.28 & 1.80 & 42.80 \\
\hline & Control package & 3 & 21.42 & 4.70 & 50.80 \\
\hline & Urinary probe & 1 & 7.14 & 0.20 & 33.90 \\
\hline & Intubation tube & 1 & 7.14 & 0.20 & 33.90 \\
\hline & Totally & 14 & 100.00 & & \\
\hline \multirow[t]{6}{*}{2016} & Bubbler water & 3 & 15.00 & 3.20 & 37.90 \\
\hline & Sterile Instruments & 9 & 45.00 & 23.10 & 68.50 \\
\hline & Soft sterile material & 4 & 20.00 & 5.70 & 43.70 \\
\hline & Urinary probe & 3 & 15.00 & 3.20 & 37.90 \\
\hline & Intubation tube & 1 & 5.00 & 0.10 & 24.90 \\
\hline & Totally & 20 & 100.00 & & \\
\hline \multirow[t]{6}{*}{2017} & Sparge water & 2 & 13.33 & 1.70 & 40.50 \\
\hline & Sterile water & 3 & 20.00 & 4.30 & 48.10 \\
\hline & Sterile Instruments & 7 & 46.66 & 21.30 & 73.40 \\
\hline & Soft sterile material & 2 & 13.33 & 1.70 & 40.50 \\
\hline & Control package & 1 & 6.66 & 0.20 & 31.90 \\
\hline & Totally & 15 & 100.00 & & \\
\hline \multirow[t]{6}{*}{2018} & Sparge water & 2 & 8.00 & 1.00 & 26.00 \\
\hline & Sterile water & 2 & 8.00 & 1.00 & 26.00 \\
\hline & Sterile Instruments & 11 & 44.00 & 24.40 & 65.10 \\
\hline & Soft sterile material & 8 & 32.00 & 14.90 & 53.50 \\
\hline & Control package & 2 & 8.00 & 1.00 & 26.00 \\
\hline & Totally & 25 & 100.00 & & \\
\hline
\end{tabular}

Table 1

HE YEARLY DISTRIBUTION OF STERILE MATERIALS COLLECTED FROM SURGICAL DEPARTMENTS (I+II)

Table 2

RESULTS OF SURGICAL MATERIALS STERILITY CONTROL

\begin{tabular}{|c|c|c|c|c|c|c|c|c|c|}
\hline \multirow[t]{2}{*}{ Year } & \multirow{2}{*}{$\begin{array}{c}\text { Total samples, } \\
\mathbf{n}\end{array}$} & \multicolumn{2}{|c|}{ Sterile samples } & \multicolumn{2}{|c|}{ 95 $\%$ C.I. } & \multicolumn{2}{|c|}{$\begin{array}{c}\text { Non-sterile } \\
\text { samples }\end{array}$} & \multicolumn{2}{|c|}{ 95\% C.I. } \\
\hline & & $\mathbf{n}$ & $\%$ & & & $\mathbf{n}$ & $\%$ & & \\
\hline 2014 & 13 & 11 & 84.61 & 54.60 & 98.10 & 2 & 15.38 & 1.90 & 45.40 \\
\hline 2015 & 14 & 14 & 100.00 & 76.80 & 100.00 & 0 & 0.00 & 0.00 & 23.20 \\
\hline 2016 & 20 & 20 & 100.00 & 83.20 & 100.00 & 0 & 0.00 & 0.00 & 16.80 \\
\hline 2017 & 15 & 15 & 100.00 & 78.20 & 100.00 & 0 & 0.00 & 0.00 & 21.80 \\
\hline 2018 & 25 & 25 & 100.00 & 86.30 & 100.00 & 0 & 0.00 & 0.00 & 13.70 \\
\hline Totally & 87 & 85 & 97.70 & 91.90 & 99.70 & 2 & 2.29 & 0.30 & 8.10 \\
\hline
\end{tabular}


For a good knowledge of the possibilities of prevention and control of nosocomial infections, it is necessary first of all to know the reality of this type of pathology, respectively, to make the surveillance strategies more efficient in all sanitary units, according to the existing legislation and professional protocols for prevention and control [27-30].

In spite of all the efforts made to prevent, control, and treat nosocomial infections, they remain a reality in our century as well, for which a sustained effort is made to reduce as much as possible their number and their consequences.

Generally, the epidemiological process of nosocomial infections, regardless of the causative agent, the clinicalepidemiological form of manifestation and the profile of the unit in which it is performed, is achieved by the interaction of three determinants: the source of the infection, the pathway of transmission and the receptivity of the organism as well as by some favorable factors (natural and socio-economic) [31-33]. Not the least, depending on the type of medical intervention performed, nosocomial infections are clearly linked also with special issues characterizing the medical devices involved, especially when multiple use and difficult to reprocess devices are used [34-36].

\section{Conclusions}

Although in most surgical departments there are generally the same types of nosocomial pathology, however, each of these departments has its own particularities, depending on the specificity of each. Thus, nosocomial infections encountered in cardiovascular surgery are: nosocomial pneumonitis, urinary tract infections, blood tissue infections, surgical wound infections, catheter-induced infections, prosthetic cardiac valve and vascular graft infections, and mediastinitis.

\section{References}

1. KENNAMER, M., Basic Infection Control for Healthcare Providers, 2nd Edition, 2006, p. 4.

2.NEAMTU, C., TOTOLICI, B.D., CRETU, O.M., STANESCU, C., ARDELEAN, A., BADEA, O., PRIBAC, G.C., CIOBANU, M.O., MATEESCU,

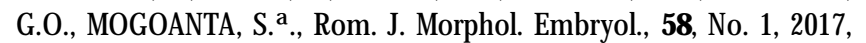
p. 235.

3.CHIRIAC, P.C., POROCH, V., PASCU, A.M., HOGEA, M.D., ANTOHE, I., LUPU, V.V., CIRLIG, V., Rev. Chim. (Bucharest), 69, no. 4, 2018, p. 915. 4.HORAN, T.C., ANDRUS, M., DUDECK, M.A., Am. J. Infect. Control, 36, 2008, p. 309.

5.BUDA, V., ANDOR, M., CRISTESCU, C., VOICU, M., SUCIU, L., MUNTEAN, C., CRETU, O., BAIBATA, D.E., GHEORGHIU, C.M., TOMESCU, M.C., Farmacia, 64, No. 3, 2016, p. 382.

6.MOGA, M.A., IRIMIE, M., OANTA, A., PASCU, A., BURTEA, V., Asian Pacific J. of Cancer Prev., 15, No. 16, 2014, p. 6887. DOI: 10.7314/ APJCP.2014.15.16.6887.

7.PEELING, R.W., MABEY, D., Clin. Microbiol. Infect., 16, No. 8, 2010, p. 1062.

8.NORRBY, S.R., NORD, C.E., FINCH, R. Lancet Infect. Dis., 5, No. 2, 2005, p. 115.

9.RUSU, M.C., CERGAN R., DERMENGIU,D., CURCA, G.C., FOLESCU, R., MOTOC, A.G., JIANU, A.M., Clin Anat., 23, No.1, 2010, p. 93. 10.HOGEA, L.M, SAS, T., POROCH, V., NUSSBAUM, L.A., SAS, I., SERBAN, D., ERDELEAN, D., FOLESCU, R., ZAMFIR, C.L, BREDICEAN, A.C., SIMU, M.A., Rev. Chim. (Bucharest), 69, no. 4, 2018, p. 934. 11.GAVRIS, C., POROCH, V., SIMION, L., BARACAN, A., TOADER, E., PASCU, A.M., Rev. Chim. (Bucharest), 68, no. 7, 2017, p. 1586.

12.BARACAN, A., GAVRIS, C., POROCH, V., TOMA, S., SIMION, L., SANDU, I., PASCU, A.M., Rev. Chim. (Bucharest), 68, no. 9, 2017, p. 2010.
13. *** Biosafety in Microbiological and Biomedical Laboratories, 5th ed., 2009. http://www.cdc.gov/biosafety/publications/bmbl5/index.htm 14.HOGEA, L.M., NUSSBAUM, L.A., CHIRIAC, D.V, AGEU, L.S, ANDREESCU, N.I., GRIGORAS, M.L., FOLESCU, R., BREDICEAN, A.C., PUIU, M., ROSCA, E.C.I., SIMU, M.A., LEVAI, C.M., Rom. J. Morphol. Embryol., 58, No. 3, 2017, pp. 767.

15.POROCH, V., AGHEORGHIESEI, D.T., Postmodern Openings, 9 , No. 2, 2018, p. 225.

16.MAINZ J ., International Journal for Quality in Health Care, 15, No. 6, 2003, p. 523.

17.MOISE, M., BURUIAN, M.M., ILIE, C., ZAMFIR, C.L., FOLESCU, R., MOTOC, A.G.M., Rom. J. Morphol. Embryol., 54, No. 4, 2013, p. 961. 18.RANSOM, S.B., JOSHI, M.S., NASH, D.B., The Healthcare Quality Book. Vision, Strategy and Tools. Health Administration Press, Chicago, Illinois, AUPHA Press, Washington D.C., 2005.

19.FOLESCU, R., ZAMFIR, C.L., SISU, A.M., MOTOC, A.G.M., ILIE, A.C., MOISE, M., Rom. J. Morphol. Embryol., 55, No. 3, 2014, p. 797.

20.MOCEAN, F., BORZAN, C., Managementul calitatii si planificarea strategica in managementul organizational din sanatatea publica. Ed. Alma Mater, Cluj-Napoca, 2003.

21.BUDA, V., ANDOR, M., PETRESCU, L., CRISTESCU, C, BAIBATA, D.E., VOICU, M., MUNTEANU, M., CITU, I., MUNTEANU, C., CRETU, O., TOMESCU, M.C., Int. J. Mol. Sci., 18, No. 2, 2017, p. 348. doi: 10.3390/ijms18020348.

22.POPESCU, M.R, ZUGUN, F.E., COJ OCARU, E., TOCAN, L., FOLESCU, R., ZAMFIR, C.L., Rom. J. Morphol. Embryol., 54, No. 2, 2013, p. 399. 23.KAYS, K.S., ENGEMANN, J.J., FULMER, E.M., CLARK, C.C., NOGA, E.M., SEXTON, D.J., Infect. Control Hosp. Epidemiol., 27, No. 3, 2006, p. 228.

24.DRAGOSTIN, I., DRAGOSTIN, O., PELIN, A.M., GRIGORE, C., ZAMFIR, C.L., J ournal of Macromolecular Science Part A - Pure and Applied Chemistry, 54, No.7, 2017, p. 489.

25.CRETU, O.M., HUT, E.F., DAN, R.G., SIMA, L.V., BLIDISEL, C.I.A., LIGHEZAN, D.F., MUNTEANU, M., RATIU, I.M., Rom. J. Morphol. Embryol., 58, No. 4, 2017, p. 1295.

26.ALEXANDRU, G.H., Managementul serviciilor medicale, Ed. EfiCon Press, Bucureoti, 2004.

27.HASSNZADEH, P., MOTAMEDIFAR, M., HADI, N., J pn. J. Infect. Dis., 62, No. 4, 2009, p. 249.

28.DRAGOSTIN, I., DRAGOSTIN, O.M., DRAGAN, M., STAN, C.D., ZAMFIR, C.L., Rev. Chim. (Bucharest), 69, no. 12, 2018, p. 3731.

29.BORUGA, O., STANCA, H.T., BAGIU, I.C., HORHAT, I.D., CRACIUNESCU, M., COSNITA, A., BERCEANU VADUVA, D., CHERCOTA, V., MILCU, A.I., IOVAN C., Rev. Chim. (Bucharest), 69, no. 4, 2018, p. 1023.

30.NICOLA, P., ARDELEANU, E., GADAU, C., DOROBANTU, M., DARABONT, R., TILEA, I., VARGA, A., FOLESCU, R., ZAMFIR, A.S., BOANCA, M., STRAT, L., BAAJ , T., GURGUS, D., Rev. Chim. (Bucharest), 69, no. 9, 2018, p. 2402

31.RATA, D.M., POPA, M., CHAILAN, J.F., ZAMFIR, C.L., PEPTU, C.A., J ournal of Nanoparticle Research, 16, No. 8, 2014, p. 2569. DOI:10.1007/ s11051-014-2569-X.

32.GANCEANU RUSU, A.R., MITITELU TARTAU, L., STATESCU, C., BOANCA, M., POROCH, V., LUPUSORU, R.V., DIMA, N, BADESCU, C., REZUS, E., REZUS, C., LUPUSORU, C.E., Rev. Chim. (Bucharest), 69, no. 6, 2018, p. 1493.

33.BERCEANU VADUVA, D.M., VELIMIROVICI, D.E., BERCEANU VADUVA, M.M., STANGA, L., PETRESCU, H., RADA, M., CIPU, D., BERCEANU VADUVA, B.M., RADULESCU, M., Mat. Plast., 55, no. 3, 2018, p. 372.

34.BALAN, G.G., PAVEL, L., SANDU, A.V., STEFANESCU, G., TRIFAN, A.V., Mat. Plast., 53, no.4, 2016, p. 791.

35.BALAN, G.G., ROSCA, I., URSU, E.L., DOROFTEI, F., BOSTANARU, A.C., HNATIUC, E., NASTASA, V., SANDRU, V., STEFANESCU, G., TRIFAN, A., MARES, M., Infection and Drug Resistance, 11, 2018, p.727.

POPA, B., ILIE, M., PLOTOGEA, O., OLTEANU, I., TURCULET, C., CONSTANTINESCU, G., Medical Ultrasonography, 17, No. 2, 2015, p. 259

$\overline{\text { Manuscript received:8.12.2018 }}$

http://www.revistadechimie.ro $\quad$ REV.CHIM.(Bucharest) $\$$ 70 No.6 2019 